\title{
Analysis of un-tensioned fully grouted rock bolt :
}

\section{A case study}

\author{
Deepanshu R Singh and Arvind K Mishra \\ Department of Mining Engineering \\ IIT (ISM) Dhanbad \\ Dhanbad, Jharkhand, India \\ arvmishra@yahoo.com
}

\author{
Harshit Agrawal \\ CSIR-CIMFR \\ Dhanbad, Jharkhand \\ India
}

\author{
Chanchal Manna \\ DGM (Mines) \\ UCIL \\ Jharkhand, India
}

\begin{abstract}
Stability of structures in any mining excavation is critical and roof rock stability has long been the primary concern in all underground excavations. There are plenty of supports systems that has evolved over the years, among them rock bolts are widely used support system in mining and various civil engineering operations. The bolts reinforce the loose and weak strata to make it, self-supportive by enhancing the inherent strength. Anchoring of the rock bolt plays an important role when deformation or movement of the layers in the rock mass induce axial tensile load in the installed rock bolts. Bolts will fail if the applied or induced axial load to the bolt is more than the anchorage strength. Anchorage strength depends on many factors such as type of bolt, annular space, grouting media, shear behavior at the bolt-grout interface, surface profile, installation mechanism and position. The paper presents performance of fully grouted un-tensioned rebar bolts in an Indian underground metal mine having competent host rock. The bolts were installed using cement (water to cement ratio 0.36) as grouting material. The embedded anchorage length was varied and a series of 30 bolts were tested to determine the anchorage strength in field conditions by conducting pull-out test at different duration from the time of installation of the bolts. Simulation studies were done using a finite difference method to analyze the redistribution of mining induced stresses due to excavation at depth of $150 \mathrm{~m}$ for the surface. The load-displacement curves were developed for the bolts subjected to in-situ pull-out test and the safety factor was analyzed for the strata when unsupported using fast lagrangian analysis of continua codes. The results indicates the successful application of un-tensioned fully grouted bolts in supporting the underground excavation. The axial deformation curve of bolts indicate the de-bonding nature along the bolt.
\end{abstract}

Keywords-Rock bolt; pull-out test; anchorage strength; numerical modelling; underground excavation; metal mining

\section{INTRODUCTION}

Strata control is a major problem affecting safety, productivity and mechanisation in underground coal and metal mines. With the advent of modern techniques associated with increased mechanisation, roof bolting has gained prominence as a primary means of support in place of traditional supports, a hindrance for achieving higher production rate and productivity apart from economic and socio-ecological considerations. Rock bolts and dowels have been used for many years for the support of underground excavations and a wide variety of bolt and dowel types have been developed to meet different needs which arise in mining and civil engineering. The principle component of reinforcement system are the rock, reinforcing bar, internal fixture and external fixture (a plate and a nut) [1]. They are generally tensioned after installation so as to make them an active support. When bolts are not tensioned or tensioning is not possible then they act like a passive support and are generally called dowels. Rock support is the term widely used to describe the procedures and materials used to improve the stability and maintain the load bearing capacity of rock near to the boundaries of an underground excavation. Thus, rock bolts not only support the weight of the unstable rock mass but also mobilize and enhance the inherent strength in the rock mass so as to control the movement of strata surrounding an opening in such a way that the availability of the opening to perform its desired function is not impaired.

The support and stability of any underground mining excavation operation, is of great concern for the engineer as any failure of strata would lead to severe concerns and loss of life of men working in certain cases. In order to stabilize any structure or strata, the condition associated has to be understood with scientific approach. There are plenty number of techniques developed over the years to support and stabilize the structure, of which rock reinforcement by bolting is a very common technique either mechanical, grouted, or anchored, and is considered to be one of the important support member, being used all over the world for more than a century. The usage of rock bolts worldwide increased extensively over the decades and was in excess of $500,000,000$ annually [2]. A rock bolt support system 
assembly consists of a ribbed bar inserted in a drilled hole into the rock or roof of mine and anchored to it by means of mechanical or grouting material. Such system is very efficient in applications such as stabilization of blocky rock masses, rock confinement and improvement of the mechanical properties of the rock [3, 4]. Easy and quick installation procedure and also the low cost as compared to other reinforcement systems are also responsible for its huge success [5]. The main function of roof bolting is to bind together roof rocks consisting of natural joints and fractures, or rocks with artificial fractures and cracks caused by the use of explosives [6]. Experience throughout the world by many researchers, to understand the mechanism of bolting assembly, behavior and assessment of grouted bolts performance has shown that de-bonding during the axial loading of rock bolt takes place either at the bolt-grout interface or at the grout-rock interface, depending on which one is weaker [7-26]. With the movement of the rock mass a load is transferred to the bolt which consequently results in the development of shear stress along the grouted length (Fig. 1). Figure shows the stress developed on the small part of the bolt length $\mathrm{dz}$, when the force acts axially.

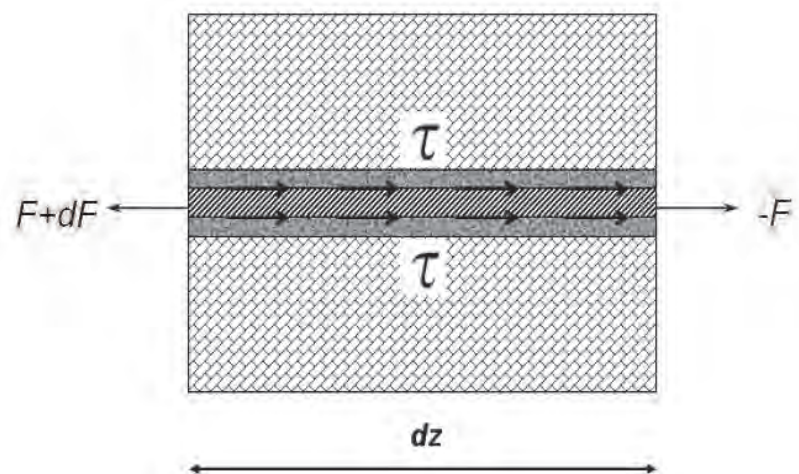

Fig. 1. Stress distribution along the length (Singh et al., 2016)

The work undertaken by the authors evaluate the support system of an underground mine using fully grouted dowel, and tries to understand and evaluate the performance of the un-tensioned rock bolt/dowel. A series of in-situ pull-out tests were conducted to generate and analyze load displacement curve of installed rock bolts in stope, which forms part of support system. The mine working was simulated using FLAC3D to understand the redistribution of mining induced stresses around the excavation at a depth of $150 \mathrm{~m}$ from the surface. The excavation was made in the hang-wall along the strike direction of the ore body.

\section{A. Load transfer mechanism of fully cement grouted rock bolts}

Full grouted rock bolts in most of the mines are used as primary as well as secondary supports. There are various grout media are available, but in situations where the rock has a measure of short-term stability, the most sufficient grout type is simple Portland cement with reinforcing untensioned rock bolts [28]. Use of cement as grouting media is one of the oldest method developed to support the roof of mine. [6] suggested that the fully cement grouted bolts are best suitable in underground excavations where the speed is not required or the rock is hard and competent in nature as the main disadvantage of fully cement-grouted bolts is the uncertainty about cement shrinkage and the longer setting time of the bolts. When using Portland cement-grouted rock reinforcement, the grout is pumped into the bore holes and the bars are driven into the filled holes. The bar will be exposed to corrosion if the grout is not fully distributed around it [29]. Rebar bolts are un-tensioned bolts and are used as both temporary and permanent support in mining as rebar tolerates high load and is a suitable support system in hard rock conditions although it requires time for the cement to cure properly, which can be a big advantage at specific conditions [30]. In order to be effective, dowels have to be installed before significant movement in the rock mass has taken place. [31] conducted series of tests to improve the understanding of the interaction mechanics of fully grouted bolts and the mine roof strata. So far, bolting patterns for required roof control are based on past experiences of trial and error methods and or empirical equations derived by others in different environment. To develop guidelines for selection of bolt type, diameter, spacing, and length in a given stress condition and geology it is essential to understand the mechanics of load transfer among parts of the grouted bolt system (bolt, grout, and the mine rock). For this purpose bolts were instrumented, in the grouted portion, with several strain gauges to investigate the load transfer along the bolt length when the bolt is pulled at the mouth using a hydraulic jack [32]. Tests were conducted at various applied loads till the failure load. It is known that the load transfer in a grouted bolt occurs in two ways, (1) Shear resistance of the grout which depends on the adhesion (actual bonding or gluing between the grout and the steel or rock), and (2) The mechanical interlocking through contact surfaces which are generally irregular as ribbed steel bars are used for bolts and the irregularities in the hole surface created during drilling. Since the adhesion between the rock surface and the grout is less in weaker/poor rock mass and therefore in such rocks longer anchorage lengths are provided because of reduced shear strength. Similarly if the grout mix is not properly mixed, or is over spun, or is glove fingered (i.e. the cartridge wrapper stuck with the rock surface or with the bolt), then the mechanical interlocking capacity of grout is reduced. In such cases the axial failure of bolt system may occur either in the bolt, the grout, the rock, or at the bolt-grout, or grout-rock interfaces. However, if the length of the bolt is sufficient to transfer the entire bolt load to the rock, then the bolt will fail only if the rock load is more than the bolt strength.

Since the steel of the bolt is always stronger and ductile than the conventional grout mix, therefore, localized failure occurs in the grout and or the rock when the magnitude of load exceeds their tensile strength. This will result in transfer of entire load on the bolt which further yields and when the bolt yield exceeds its capacity then the local failure of the bolt takes place. Subsequently, the load transfer progresses along the remaining portion of the bolt length. However, if the bolt length is insufficient to transfer the bolt load to the rock then the localized failure will occur at the weakest area. In such cases redesigning of bolting 
pattern is required either by increasing bolt length, bolt diameter, or spacing.

\section{STRESSES IN HARD ROCK AND AROUND OPENING}

Whenever an underground excavation is carried out the stresses induced due to excavation is redistributed uniformly with increase in the magnitude of vertical stress as the depth of excavation increases. With change in the original equilibrium of stress the unsupported span directly above the opening loses its original support. As a result, the load of the immediate roof is transferred towards the both sides of the opening, which is called abutments. The roof starts to sag under the gravitational force. If the immediate roof strata are competent, the sag will stop before the roof collapses and the stresses around the opening will eventually reach a new equilibrium. In hard and brittle rock, failure or fracturing occurs when the shear or tangential stresses exceeds the rock mass strength mainly at the boundary of excavation depending on the shape of the excavation. The stress disturbance creates five influential zones around a rectangular opening [6] as shown in Fig. 2. To maintain the stability of an underground opening, it is essential to keep Zone 1 stable. Roof bolts in this zone force all the bolted rock mass to deform with the same magnitude; the layers within the bolting range thus act like a solid beam. The severity of spalling can vary from minor spalling to the complete collapse of excavations. When the rock stresses are very high (i.e., tangential stresses are much higher than rock mass strength) the rock mass may fail with loud sounds in brittle rocks, leading to rock burst [33].

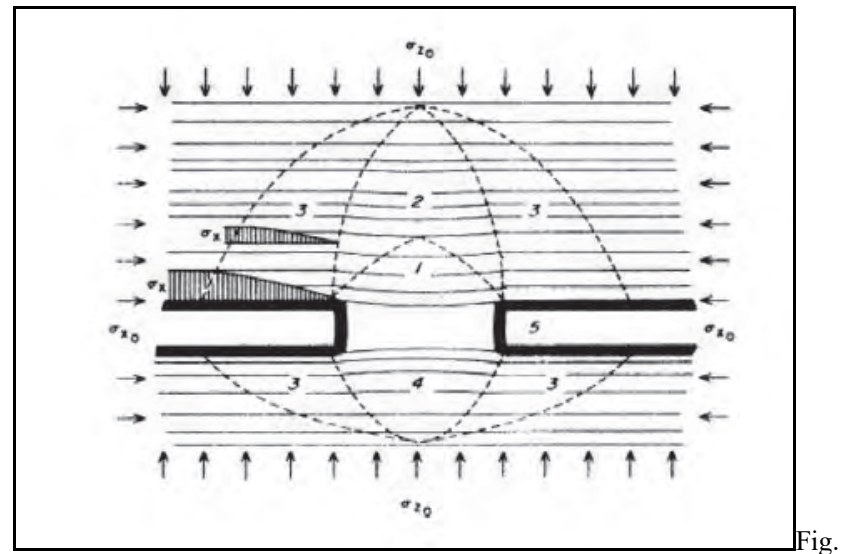

2. Stress distribution around a rectangular opening in underground mine drive soon after excavation - mark 5 influence zones created around a rectangular opening [6]

- Zone 1- Bed separation due to differential sag or buckling

- Zone 2- Layers sag without separation. Gravity acts to develop sags in Zone 1 and 2

- Zone 3-Horizontal and vertical pressure build to their undisturbed values

- Zone 4- Floor heave occurs without bed separation

- Zone 5- Seam expands towards excavation because of release of horizontal stress

When the stress concentrations are higher in the nearby field or opening then there is sudden release of geologic strain energy known as rock burst. Rock burst is a serious problem that may lead to unwanted and dangerous situations in any underground excavations which can also leads to loss of human life in several cases [34].

\section{Methodology}

\section{A. Site Details}

The study was conducted at an underground metal mine. The ore body at the mine is lenticular and explored up to the depth of 600 meters from surface. The strike length of the ore body is about 600 meters with average thickness of 8 meters dipping towards north-east at an inclination of about 37o. At present the mine is developed up to 175 meter depth from surface, with three stoping levels at $60 \mathrm{ML}, 100$ ML and 150ML. The method of extraction is by cut- $\&$-fill method. The in-situ stresses has been measured and found to be:

$$
\begin{gathered}
\mathrm{S}_{\mathrm{H}}=2.51+0.0472 \mathrm{H}, \mathrm{MPa} \\
\mathrm{S}_{\mathrm{h}}=1.96+0.0236 \mathrm{H}, \mathrm{MPa} \\
\mathrm{S}_{\mathrm{v}}=0.0281 \mathrm{H}, \mathrm{MPa}
\end{gathered}
$$

Where, $\mathrm{S}_{\mathrm{H}}$ is the maximum horizontal in-situ stress, $\mathrm{S}_{\mathrm{h}}$ is the minimum horizontal in-situ stress and $S_{v}$ is the vertical in-situ stress.

The host rock of the mine is very hard and competent as the calculated RMR as per CMRI-ISM method is 65 . The samples were taken from $150 \mathrm{ML}$ to determine the geotechnical properties of the mine. Table I tabulates the geotechnical properties of the host rock. Three sets of joints were observed in the roof rocks and their strike, dip direction and dip amount was measured using Brunton Compass. The first set is oriented $\mathrm{N} 15^{\circ}$ and dipping $75^{\circ}$ towards $\mathrm{S} 15^{\circ} \mathrm{E}$. Second set strikes $\mathrm{N} 210^{\circ}$ and dips $75^{\circ}$ towards $\mathrm{N} 60^{\circ} \mathrm{W}$. Third set, which is not very prominent strikes $\mathrm{N} 110^{\circ}$ and dips $55^{\circ}$ towards $\mathrm{N} 20^{\circ} \mathrm{E}$. Some gauge filling is also noticed at a few locations in joints otherwise joints are tightly held with no filling. The mine roof is dry. The tests were conducted on fully grouted rock bolts installed at $150 \mathrm{ML}$ stope. The average thickness of the ore body was $8 \mathrm{~m}$.

TABLE I. Summary Of Strength Properties Of Rock MAterial

\begin{tabular}{|l|c|}
\hline \multicolumn{1}{|c|}{ Properties } & Values \\
\hline Uniaxial compressive strength, $\sigma_{\mathrm{c}}(\mathrm{MPa})$ & 65 \\
\hline Tensile strength, $\sigma_{\mathrm{t}}(\mathrm{MPa})$ & 10 \\
\hline Young's modulus, $\mathrm{E}(\mathrm{GPa})$ & 4.95 \\
\hline Poission ratio, $v$ & 0.25 \\
\hline Density $(\mathrm{g} / \mathrm{cc})$ & 2.82 \\
\hline Cohesion, $\mathrm{C}(\mathrm{MPa})$ & 22.06 \\
\hline Friction angle, $\left({ }^{\circ}\right)$ & 44.5 \\
\hline
\end{tabular}

\section{B. Numerical Modelling}

Numerical modelling is a handy mathematical tool for assessing the performance of complex geotechnical and mining structures under varying stress conditions prevailing at actual mine sites [35]. There are many constitutive models developed, to understand the behaviour of rock bolts under 
various loading conditions to solve the geo-technical issues by the numerical modelling analysis [36]. It gives the freedom of conducting parametric study in order to assess feasible geotechnical design for mining methods and structures. The models were used sometimes partially to analyze the support (roof bolting) system in mines with specific in-situ conditions and stress occurring at the mine sites. With the development in technology it is noted and accepted that $3 \mathrm{D}$ models gives a better picture and makes analysis a lot easier for the geo-technical engineers and scientists to analyze bolting system. The main advantage of the numerical model is that it can simulate the actual field conditions and offers a faster alternative to actual field observation which may get risky at times and involves a great ordeal of time and money [37]. Numerical modelling gives liberty to select parameters which may not be feasible in actual site condition, thus assessing the influence of various related geotechnical parameters on stability of an underground structure (Burke, 2003). With the advancements in numerical modelling techniques and development of new mathematical procedures, algorithms and computational methods for solving geo-technical problems, investigation of complex geotechnical problems have become easier [36]. There exists several numerical methods to simulate the responses of rock and to evaluate the performance of the bolts installed to support the excavated strata in the mines. The commonly used numerical methods are Finite Difference Method (FDM), Boundary Element Method (BEM), Finite Element method (FEM) and Discrete Element Method (DEM). A three-dimensional finite difference program, using Fast Langrangian Analysis of Continua (FLAC3D) is used to simulate the mining condition before and after excavation, and an attempt has been made to install rock bolts to the excavated span. FLAC3D has been extensively used in mining applications for mechanical loading and deformations, evaluation of progressive failure and collapse in hard rock mine and tunnel design, factor of safety calculation in stability analysis, mine designing, restraint provided by cable support on geological material, time dependent creep behavior, dynamic loading on slip-prone geologic structures, analysis of highly deformable materials like mine caving, etc. [37, 38, 39]. The Lagrangian calculation and mixed discretization zoning technique used in FLAC3D ensures plastic collapse and flow are modelled very accurately. [40] used FLAC3D time-stepping approach for stress analysis and assessed the stability of underground workings. Many researchers have used the software for the modelling of the rock bolt element and tried to simulate the bolts subjected to various loading conditions [41- 48] Input parameters are vital for any numerical modelling exercises. Before applying any numerical modelling technique, all the geo-mining conditions pertaining to the basics of given geotechnical problem need to be defined [35]. These parameters mainly include geometry of the area to be studied, rock properties (like elastic modulus, poisons ratio, density, etc.), pre-excavation in-situ field stresses, etc. Necessary boundary conditions need to be applied and meshing as per the dictate of the software is to be properly done. The grids were suitably generated to simulate the workings of underground hard rock mine. The virgin model was generated at requisite mesh size to simulate the dip of the lenticular deposit to simulate actual field condition as

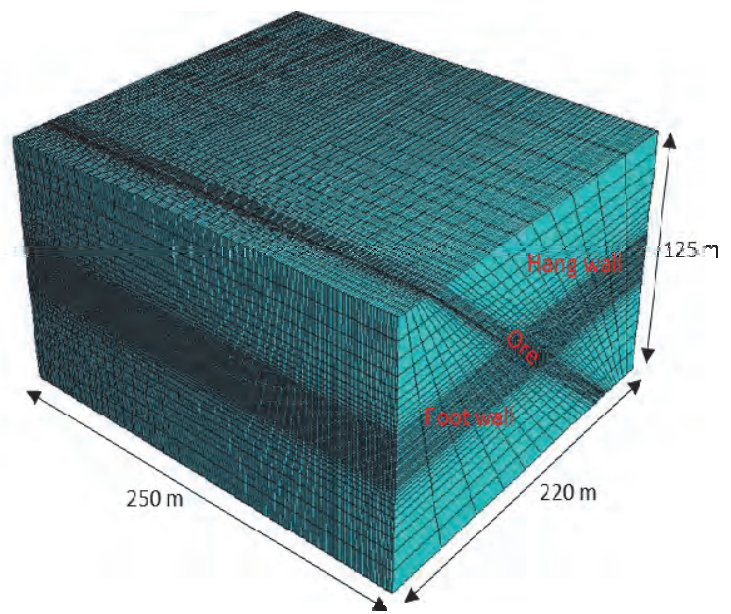

Fig. 3. Grid generation for lenticular deposit of ore body

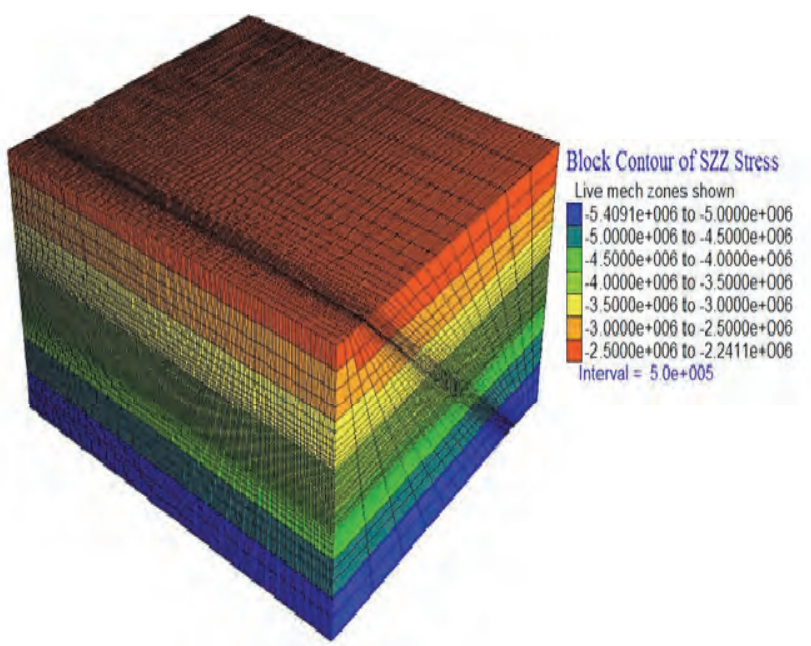

Fig. 4. In-situ zone contour of vertical stresses in pre-mined condition

shown in Fig. 3. The virgin model was developed having $220 \mathrm{~m}$ along $\mathrm{X}$-direction, $250 \mathrm{~m}$ along $\mathrm{Y}$-direction and $125 \mathrm{~m}$ along Z-direction respectively. Symmetry have been gainfully used to simulate a vast underground metal mining panel. After the in-situ grid is generated as per the actual site working condition, the model is loaded with in-situ stress values prevalent at the site location (eqns. 1- 3) and rock properties as detailed in Table I and as shown in Fig. 4. In order to simulate working situation truncated load of requisite magnitude have been applied at the upper Zboundary with rolling boundaries along $\mathrm{X}$ and $\mathrm{Y}$ directions. The in-situ vertical stress contours is shown in Fig. 4 representing different amount of stresses occurring at different depth of working. The stress follows the gradient with depth of working as gravity loading conditions have been taken. The minining method used for the extraction is cut and fill method. In order to simulate the mining method 
initially a drive of $3 \mathrm{~m}$ in Z-direction in ore body along the strike direction of the ore was driven. The cross section of the drive taken was $8 \mathrm{~m} \mathrm{X} 3 \mathrm{~m}$. To understand the stress redistribution after the excavation has been made the strata was not reinforced using any support element. Development model were made to simulate the excavation made at $21.6 \mathrm{~m}$, $108 \mathrm{~m}$ and $250 \mathrm{~m}$ along the strike direction. A representative figure is shown in Fig. 5, in $21.6 \mathrm{~m}$ development with stress profile around the opening. The maximum in-situ vertical stress of 10.2 MPa has been observed.

\section{Support Design and Procedure}

The Hanging Wall is supported with TMT bar rock bolt at $1.2 \mathrm{~m} \times 1.2 \mathrm{~m}$ intervals in grid pattern. The back is supported with rock bolts at $1.5 \mathrm{~m} \times 1.5 \mathrm{~m}$ intervals in grid pattern. Full column cement grout type rock bolts, TMT bar $22 \mathrm{~mm}$ (with rib) diameter and 2.4 meter long for Hang wall \& 1.6 meter long for back with a 'eye' at one end were used. The mine does not require any other support type except than bolt. No accident has been reported till date and the bolts are capable of supporting the roof rock. The support design at the testing area is shown in Fig. 6.

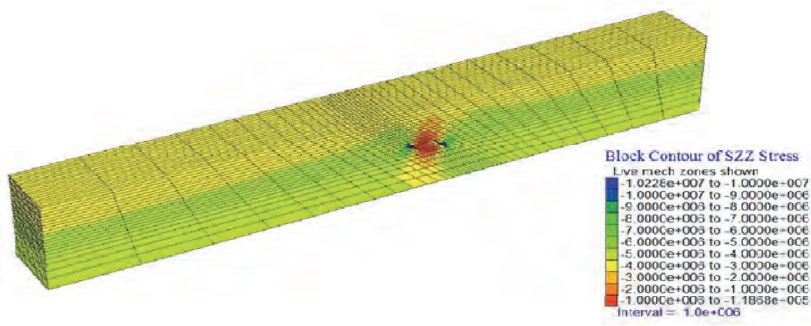

Fig. 5. Simulated model of drive along the ore strike and stresses induced due to excavation

The rock is hard and only rock bolts are required to support the rock. The conditions are such that installation of rock bolt can be carried out very close to an advancing face and stress change is not much significant. In these conditions un-tensioned rock bolts commonly known as dowels are used in place of tensioned rock bolts.

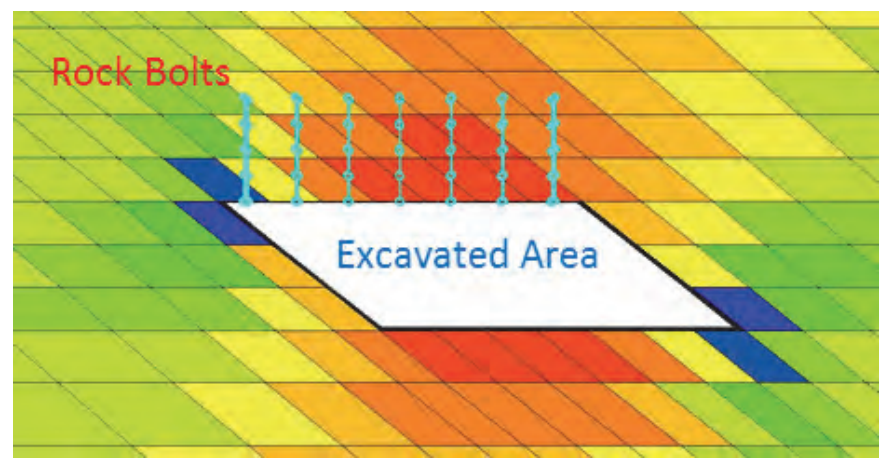

Fig. 6. Support design at $150 \mathrm{ML}$ stope

Draw points, which are mined before the overlying stopes are blasted, are good examples of excavations where un-tensioned grouted rock bolt will work well [49]. The essential difference between these systems is that tensioned rock bolts apply a positive force to the rock, while untensioned rock bolts/dowels depend upon movement in the rock to activate the reinforcing action. Fig. 7 shows the bolting procedure practiced in mines to install the fully grouted rock dowels and an installed rock dowel. A thick grout $(0.35$ water cement ratio grout $)$ is pumped into the hole pneumatically by inserting the grout tube to the end of the hole and slowly withdrawing the tube as the grout is pumped in. Special attention is given that there is no air cavity formation in the hole. The rock bolt is pushed into the hole about half way and then given a sudden push to insert fully into the hole.

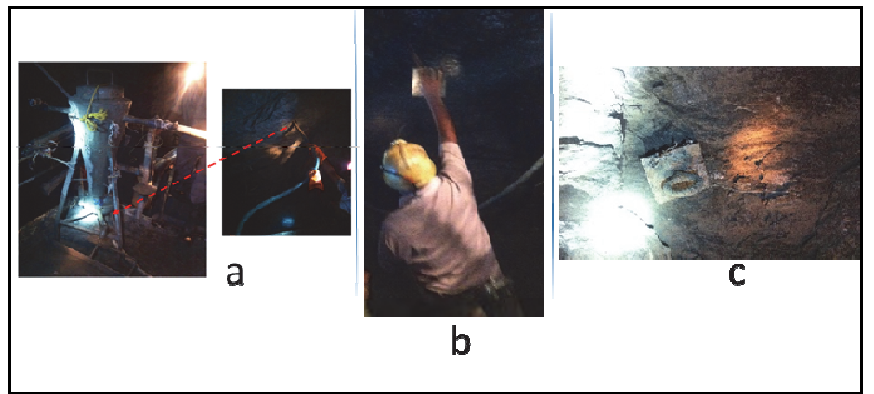

Fig. 7. Installation of fully grouted rock bolt in mines; a: Insertion of grout in the hole; b: Insertion of rock bolt in the hole; c: Installed rock bolt

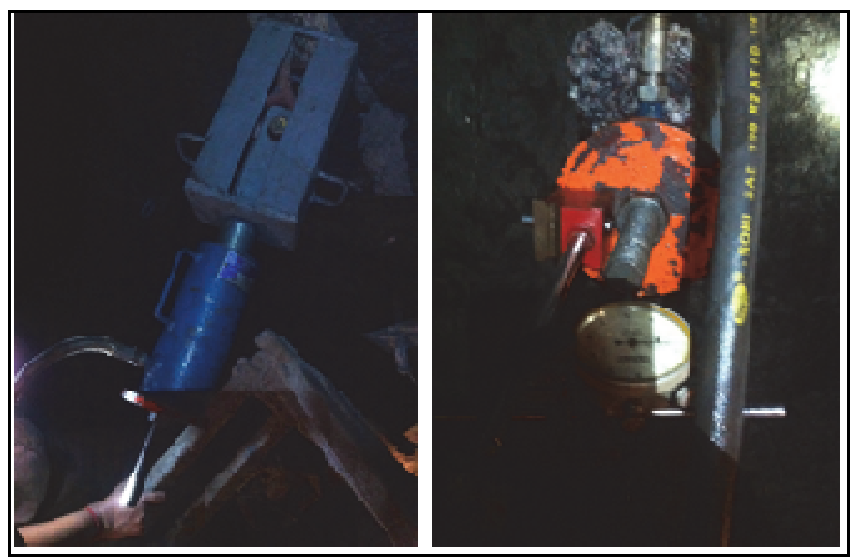

Fig. 8. Rock bolt anchorage testing assembly

\section{Pull-out test}

Pull-out testing does not measure the entire roof support system nor include tests for pre-tensioned bolts or evaluation on mine roof support system. Pull-out tests apply to mechanically, cement- and resin-grouted, or other similar anchor systems. Information gathered from pull-out tests may give a quantitative measure of the relative performance of anchor system in the same rock type. The rock bolts and dowels tested were installed in percussion drilled holes using the installation techniques which would be used in a normal underground mining operation. The pull-out test were conducted in the mines to know the anchorage strength of the un-tensioned rock bolts installed in the stope. A series of 30 bolts were pulled to understand the performance of fully grouted bolts under axial loading using the hydraulic pump to pull-out the fully grouted rock bolts. The displacement of the bolts corresponding to applied load was recorded using dial gauge. The testing assembly is with dial gauge arrangement is shown in Fig. 8. 
In order to ensure accurate drilling of holes and drilling depth the steel rod were marked and the drill used was same for all holes. Proper care was taken during the mixing of grout constitute so that the ratio is maintained properly. The installation time for one bolt was approximately 36 seconds. The other parameters such as hole diameter, grout type and constitutes, length of the bolt, diameter of the bolt, surface profile, installation procedure, testing procedure and rock type and test location were kept same for all the tests. The test were conducted at different time after installing of the bolt i.e. 30 minutes, 2 hours, 24 hours, 7 days and 28 days.

\section{Pull-out Test Results}

Fig. 9 shows the observed load deformation curve for the in-situ pull-out test in hard rock conditions at different time intervals of 28 days, 7 days and 24 hours. The results confirmed that the anchorage strength of the fully grouted cement grout depends on the strength of the grout, as the no strength is observed after time interval of 30 minutes or 2 hours, but after 24 hours the bolt develops some anchorage strength. Initially the load deformation curve is more or less linear in nature. However as the bond between the grout and bolt breaks near the collar of the hole the deformation increases and as the peak load is reached the anchor began to slip and de-bonding between the grout and bolt occurs. The anchor begins to slip and after peak strength the anchor still goes on to $80 \%$ of the peak load with $12-14 \mathrm{~mm}$ deformation. For 7 days the peak load achieved was less than the 28 days because of the grout strength and curing time. Here also the load carries up to $80 \%$ of the peak load but with higher deformation of 15-18 mm deformation. Deformation curve of 24 days shows low peak load and high deformation for the low axial loads also as the curing time is not sufficient enough and de-bonding of bolt and grout interface near the collar occurs with slip at lower axial load than 28 days and 7 days test. After attaining peak load the load goes on to $85 \%$ with deformation of 5-7 mm only. Table II contains the summary of the test for each time interval. A series of 12 bolts were tested for 28 days, 11 bolts after 7 days and 7 bolts after 24 hour time interval. The bolt diameter, hole diameter and grouting material were kept same for all the test to understand the in-situ bolt performance with variation in time after the installation of the bolt. A total of 2 and 3 pull-out test were conducted for the 30 minutes and 2 hours' time interval respectively but the results were not of much importance as the grout was not cured and the bolts came out very easily.

The bonding between the bolt and the grout was not significant with no shear resistance or strength between the interfaces. The anchorage strength of the rock bolt/dowel after 30 minutes and 2 hours were very marginal and the bolt was pulled by the weight of the hydraulic testing equipment itself. The After 2 hours the bolts were pulled and the gloving of cement grout can be observed around the bolt indicating the proper mixture of the grout. The test confirmed that the anchorage strength of cement grouted dowel is achieved after 24 hours and is significantly high for the Portland cement grouted bolt. In some of the bolts the

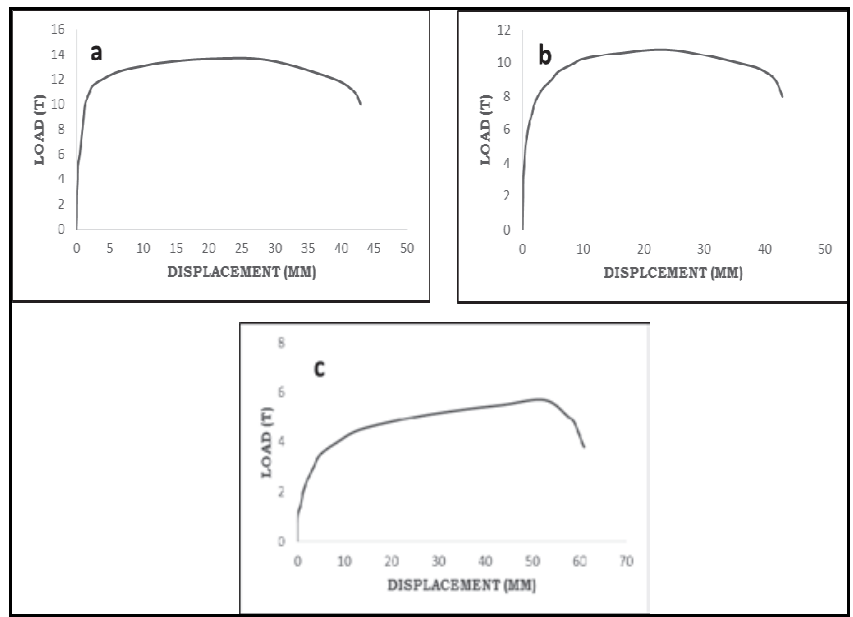

Fig. 9. Load deformation curve for axial pull-out test in hard rock mines at different time intervals; a: 28 days; b: 7 days; c: 24 hours

peak load reached up to $18 \mathrm{~T}$ after 28 days. In one test the bolt start to bend near the collar and the load was not getting transfer to the length of the bolt. This may have happened due to improper installation of the bolt in the hole because of which the load was not completely axial in nature. It is also seen that the hydraulic pump reached it maximum rated capacity still the bolt peak load has not reached, but some crushed grout was coming out of the hole may be because of the crushing or wedge formation inside the hole. The mine roof was dry and no water seepage was present in the holes.

\section{DISCUSSION AND CONCLUSIONS}

The type of support design vary with mine to mine strata conditions. The pre-tensioned rock bolts for reinforcing the unsupported roof are most common roof bolting practice in mines. The use of un-tensioned rock bolts are now phasing out, although they are effective in long term stability and can be best suited to the certain specific applications such as in metal mines. The un-tensioned rock bolts acts as passive support during the time of installation and later on as the movement of rock takes they get loaded and becomes active support. The results from the modelling shows the stress value while developing the host rock and a change of 5.4 $\mathrm{MPa}$ to $10.2 \mathrm{MPa}$ was noticed before and after excavation with no support. The results obtained during the study of insitu pull-out test at different time interval to understand the performance of fully cement grouted rock bolt shows that the bolt after 7 days and 28 days of installation have significantly high anchorage strength with deformation of 42-46 mm. A high de-bonding of bolt with the grout is observed after time interval of 24 hours and consequently a low peak anchorage strength. Special attention has been given on the installation of the bolt so that the load remain axial during the test. In mines where the rock is competent with less horizontal stress the application of dowel or fully cement grouted un-tensioned rock bolt are still feasible option available. The numerically model of mine before and after excavation shows the competency of the rock with no layering. Installation of bolts can be carried out very close to an advancing face in anticipation of stress change which will occur at a later mining stage. With the results obtained 
it can be said that the fully grouted un-tensioned bolts can be used as support in the metal mine with competent roof conditions, although still the subjects needs more research to analyze the stress coming along the length of the bolts after installation. The long term stability can be achieved as the bolts shows comparatively better performance after 28 days of the installation and successfully supports mine roof.

\section{ACKNOWLEDGMENT}

The authors are thankful to Director of associated institutions and organization for their encouragement, support and kind permission to publish and present this paper. The views expressed in this paper are that of the authors and not necessarily of the organizations they belong to.

\section{REFERENCES}

1] C.R. Windsor, and A.G. Thompson, "Rock reinforcementtechnology, testing, design and evaluation", Comprehensive Rock Engineering (Ed. J.A. Hudson). Oxford: Pergamon Press, 1993.

[2] C.R. Winsdor, "Rock reinforcement systems", Int. Jr. Rock Mech. Min. Sci., vol. 34(6), 1997, pp- 919-951.

[3] B.A. Chappell, "Rock bolts and shear stiffness in jointed rock mass", Journal of Geotechnical and Geo-environmental Engineering, $1989,115 \mathrm{p}$.

[4] J. Fine, "In Le soutènement des galeries minières", Les Presses de l'Ecole des Mines de Paris, 1998, pp- 199-220.

[5] B. Stillborg, "Professional Users Handbook for Rock Bolting", Trans Tech Publications, 1986.

[6] S. Peng, and D. Tang, "Roof Bolting in Underground Mining: State of the ArtView", Int. Jr. Min. Engg., vol. 2, 1984, pp-1-42.

[7] I.W. Farmer, "Stress Distribution along a Resin Grouted Rock Anchor", Int. Jr. Rock Mech. Min. Sci., vol 12, 1975, pp- 347 351.

[8] T.J. Freeman, "The behaviour of fully-bonded rock bolts in the Kielder experimental tunnel", Tunnels and Tunnelling, 1978, pp$37-40$.

[9] H. Larson, and T. Olofsson, "Bolt action in jointed rock", In: Proc. International Symposium on Rock Bolting, Abisko (Sweden), $28^{\text {th }} \quad$ August-2 ${ }^{\text {nd }}$ September 1983 ,Publ: A.A. Balkema, Rotterdam, pp-33-46.

[10]H. Stille, M. Holmberg, and G. Nord, (1989): "Support of weak rock with grouted bolts and shotcrete", Int. Jr. Rock Mech. Min. Sci. and Geo-mech. Abstr., vol. 26(1), 1989, pp-99-113

[11] B. Indraratna, and P.K. Kaiser, "Analytical model for the design of grouted rock bolts" International Journal for Numerical and Analytical Methods in Geo-mechanics, vol. 14(4): 1990, pp-227251

[12] P.K. Kaiser, and S. Yacizi, "Bond Strength of Grouted Cable Bolts", Int. Jr. Rock Mech. Min. Sci., vol. 29, 1992, pp-279-292.

[13]B. Benmokrane, A. Chennouf, and H.S. Mitri, "Laboratory Evaluation of Cement-Based Grouts and Grouted Rock Anchors", Int. Jr. Rock Mech. Min. Sci., vol. 32, 1995, pp- 633642.

[14] A.J. Hyett, W.F. Bawden, G.R. Macsporran, and M. Moosavi, "A Constitutive Law for Bond Failure of Fully-grouted Cable Bolts Using a Modified Hoek Cell”, Int. Jr. Rock Mech. Min. Sci., vol. 32, 1995, pp-11-36.

[15]P.G. Fuller, B.G. Hume, and R.G. Hume, "Bolt load simulation and its practical application", Rock mechanics, eds. Aubertin, Hassani \& Mitri, Publ. A.A. Balkema, Rotterdam, 1996, pp-187193.

[16] C. Li, and B. Stillborg, "Analytical models for rock bolts", Int. Jr. Rock Mech. Min. Sci. vol. 36, 1999, pp-1013-1029.
[17]Z. Huang, E. Broch, and M. Lu, "Cavern roof stability mechanism of arching and stabilization by rock bolting" Tunnelling and Underground Space Technology, vol. 17(3), 2002, pp- 249- 261.

[18] Y. Cai, T. Esaki, and Y. Jiang, (2004): "An analytical model to predict axial load in grouted rock bolt for soft rock tunneling" Tunneling and Underground Space Technology, vol. 19(6), 2004, pp-607- 618

[19] P.C. Hagan, "Variation in load transfer of a fully encapsulated rock bolt", In: Proc. 23 International Conference on Ground Control in Mining. Morgantown. Australia, 2004.

[20] M. Moosavi, A. Jafari, and A. Khosravi, (2005): "Bond of cement grouted reinforcing bars under constant radial pressure", Cement and Concrete Composites, vol. 27, 2005, pp.103-109.

[21] L. Malmgren, and E. Nordlund, "Interaction of shotcrete with rock and rock bolts - a numerical study", Int. Jr. Rock Mech. Min. Sci., vol. 45(4), 2008, pp-538- 553.

[22] C. Carranza-Torres, "Analytical and numerical study of the mechanics of rock bolt reinforcement around tunnels in rock masses" Rock Mechanics and Rock Engineering, vol. 42(2), 2009, pp-175-228.

[23] A. Ivanović, and R.D. Neilson, "Modelling of de-bonding along the fixed anchor length", Int. Jr. Rock Mech. Min. Sci., vol. 46 , 2009, pp-699-707.

[24] A. Bobet, and H.H. Einstein, "Tunnel reinforcement with rock bolts", Tunnelling and Underground Space Technology, vol. 26(1), 2011, pp- 100- 123

[25]C.C. $\mathrm{Li}$, "A review on the performance of conventional and energy-absorbing rock bolts", Jr. Rock Mech. Geotech. Engg., vol. 6(4), 2014, pp-315-327

[26] H. Lin, Z. Xiong, T. Liu, R. Cao, and P. Cao, "Numerical simulations of the effect of bolt inclination on the shear strength of rock joints", Int. Jr. Rock Mech. Min. Sci., vol. 66, 2014, pp49-56.

[27] D.R. Singh, A.K. Mishra, and H. Agrawal, "Performance evaluation of fully grouted rock bolt in an Indian hard rock underground mine", In Pro. INDOROCK, ISRMTT, 2016, pp. 741-755, IIT Bombay.

[28] A. Kilıc, E. Yasar, and A.G. Celik, "Effect of grout properties on the pull-out load capacity of fully grouted rock bolt", Tunnelling and Underground Space Technology, vol. 17, 2002, pp-355-362

[29]F.S. Kendorski, "Rock and reinforcement-longevity", United States: Geo Institute, 2003.

[30]C.C. Li, "Rock and Soil Mechanics - Supplements", Trondheim: Department of Geology and Mineral Resources Engineering NTNU, 2013.

[31] R.N. Gupta, "Improvement of roof control by laterally confined fully grouted bolts", 27th Int. Conf. on Safety in Mines Research Institute, 1997, New Delhi, India

[32] S.P. Signer, "Field verification of load transfer mechanism of fully grouted rock bolts", US Bureau of Mines (9301), 1990

[33] C.C. Li, and C. Doucet, "Performance of D-Bolts under dynamic loading", Rock Mechanics and Rock Engineering, vol. 45(2) 2012, pp. 193-204.

[34]E. Hoek, "The development of rock engineering", Retrieved $24^{\text {th }}$ February 2016, from http://www.rocscience.com/hoek/corner/1_The_development_of rock engineering.pdf., 2007.

[35] H. Agrawal, S.K. Singh, P.K. Mandal, and A.P. Singh, "3Dimensional numerical modelling: An effective enabler for CM deployment in coal seams" J. Mines Metals and Fuels, May-June 2015, pp-111-118.

[36] Itasca, User manual for FLAC ${ }^{3 \mathrm{D}}$ version 3.1, Itasca Consulting Group Inc., Minnesota, USA, 2006.

[37] A. Sarathchandran, "Three dimensional numerical modeling of coal mine roadways under high horizontal stress fields", Master of Science dissertation. University of Exeter in Mining Resource Engineering, 2014, 108p.

[38] M. Cai, "Influence of stress path on tunnel excavation response Numerical tool selection and modelling strategy", Tunnelling and Underground Space Technology, vol. 23(6), 2008, pp. 618628. 
[39] N. Vlachopoulos, and M.S. Diederichs, "Appropriate Uses and Practical Limitations of 2D Numerical Analysis of Tunnels and Tunnel Support Response", Int. Jr. Geotech. Geol. Engg., ISSN: 0960-3182, DOI 10.1007/s10706-014-9727-x, Springer, published online $14^{\text {th }}$ Jan 2014, pp. 1-22.

[40] G. Wenbing, and X. Feiya, "Numerical simulation of overburden and surface movements for Wongawilli strip pillar mining", Int. Jr. Min. Sci. and Tech., vol. 26, 2016, pp. 71-76.

[41] W. Gale, C. Mark, D. Oyler, and J. Chen, "Computer simulation of ground behaviour and rock bolt interaction at Emerald mine", $23^{\text {rd }}$ International conference on ground control in mining, 2004, pp 27-34.

[42] C. Mark, W. Gayle, D. Oyler, and J. Chen, (2007). "Case history of the response of a longwall entry subjected to concentrated horizontal stress", International Journal of Rock Mechanics and Mining Sciences, vol. 44(2), 2007, pp. 210-221.

[43]H.Y. Liu, J.C. Small, and J.P. Carter, "Full 3D modelling for effects of tunnelling on existing support system in Sydney region", Tunnelling and Underground Space Technology, vol. 23(4), 2008, 399-420.

[44] C. Carranza-Torres, "Analytical and numerical study of the mechanics of rock bolt reinforcement around tunnels in rock masses", Rock Mechanics and Rock Engineering, vol. 42(2), 2009, pp.175-228.

[45]F.F. Ren, Z.J. Yang, J.F. Chen, and W.W. Chen, "An analytical analysis of the full range behaviour of grouted rock bolts based on a tri-linear bond-slip model" Construction and Building Materials, vol. 24, 2009, pp. 361-370.

[46]F.F. Ren, Z.J. Yang, J.F. Chen, and W.W. Chen, (2010). “An analytical analysis of the full range behaviour of grouted rock bolts based on a tri-linear bond-slip model" Construction and Building Materials, vol. 24(3), 2010, pp. 361-370.

[47] L. Blanco Martin, M. Tijani, and F. Hadj-Hassen, "A new analytical solution to the mechanical behaviour of fully grouted rock bolts subjected to pull-out tests", Construction and Building Materials, vol. 25(2), 2011, pp. 749-755.

[48] S. Ma, J. Nemchik, and N. Aziz, "An analytical model of fully grouted rock bolts subjected to tensile load", Construction and Building Materials, vol. 49(0), 2013, pp. 519-526.

[49] E. Hoek, P.K. Kaiser, and W.F. Bawden, "Support of underground excavations in hard rock", CRC Press, 2000. 